\title{
Regulation of Toxin Biosynthesis by Plasmids in Vibrio cholerae
}

\author{
By A. A. KHAN, RANJANA SRIVASTAVA, V. B. SINHA \\ AND BRAHM S. SRIVASTAVA* \\ Cholera Immunology, Microbiology Dicision, Central Drug Research Institute, \\ Lucknow 226001, India
}

(Receiced 13 February 1985; revised 29 April 1985)

\begin{abstract}
Vibrio cholerae strain 569B Inaba harbouring $\mathrm{P}$ plasmid produced less toxin than the parent strain. To examine the effect of plasmid loss on toxin production, temperature-sensitive (ts) mutants of $\mathrm{P}$, unable to replicate at $42{ }^{\circ} \mathrm{C}$, were isolated. One ts plasmid was unstable at $42{ }^{\circ} \mathrm{C}$ and its loss yielded a cured strain that resumed a normal level of toxin biosynthesis characteristic of the plasmid-free parent strain. Toxin production was again suppressed in the cured strain after reacquisition of $\mathrm{P}$ plasmid. This suggested a role for plasmid-borne genes in the regulation of toxin biosynthesis. A mutant of strain 569B Inaba that produced mutant toxin was isolated by transfer of $\mathrm{P}$ and $\mathrm{V}$ plasmids. The mutant toxin was similar to choleragenoid because it did not give rise to symptoms of cholera but induced antitoxin immunity in rabbits.
\end{abstract}

\section{INTRODUCTION}

Cholera toxin produced by Vibrio cholerae is a multimeric protein consisting of one A and five B subunits (Gill, 1976), and the genes encoding and regulating toxin biosynthesis appear to be located on the $V$. cholerae chromosome (Mekalanos et al., 1979; Sporecke et al., 1984). Sinha \& Srivastava $(1978 a, b)$ observed suppression of virulence of $V$. cholerae after acquisition of $\mathbf{P}$ and/or V plasmids, which was associated with partial or complete inhibition of toxin biosynthesis. The A subunit of cholera toxin promotes activation of adenylate cyclase by a NAD-dependent reaction (Gill \& Meren, 1978). The B subunit of the toxin, also referred to as choleragenoid, may be considered a natural toxoid, stimulating antitoxin immunity (Holmgren et al., 1977). $\mathrm{A}^{-} \mathrm{B}^{+}$strains attenuated by classical mutagenesis (Honda \& Finkelstein, 1979) and by recombinant DNA techniques (Mekalanos et al., 1983; Kaper et al., 1984) have been isolated.

The objective of our study was to cure $V$. cholerae cells of plasmids and to determine whether the loss of plasmid resulted in reversion to a normal level of toxin biosynthesis as in isogenic strains devoid of plasmids.

\section{METHODS}

Media. Broth cultures of bacteria were raised in Difco Bacto Brain Heart Infusion (BHI: $37 \mathrm{~g}$ in 1 litre distilled water). Bacterial plating was done on Difco nutrient agar plates (NA; $8 \mathrm{~g}$ Difco nutrient broth, $5 \mathrm{~g} \mathrm{NaCl}, 10 \mathrm{~g}$ Oxoid agar in 1 litre distilled water). Syncase sucrose minimal medium was prepared as described by Finkelstein $\&$ LoSpalluto (1969). Phosphate-buffered saline (PBS; pH 7.2) was routinely used for bacterial dilution (Sinha \& Srivastava, 1978). An aqueous solution of ampicillin (Ap, $100 \mu \mathrm{g} \mathrm{ml}^{-1}$ ) was filter-sterilized and added after the media were autoclaved.

Bacteria. Escherichia coli CSH41 harbours the conjugative plasmid RP4 which carries the Ap determinant transposon $\mathrm{Tn} 1$; this transposon was transposed onto the $\mathrm{P}$ plasmid of $V$. cholerae to introduce a genetic marker for plasmid identification. $V$. cholerae CD63 was characterized as harbouring $\mathrm{P}:: \mathrm{Tn} /$ and Apr.

Abbreviations: HA, haemagglutination; SRBC, sheep red blood cells. 
$V$. cholerae $\mathrm{CD} 65$ and $\mathrm{CD} 66$ harbour the temperature-sensitive plasmid ts $\mathrm{P}:: \mathrm{Tn} /$ (see below). CD68 is a cured isolate of CD66. It was isolated by growing CD66 at $42{ }^{\circ} \mathrm{C}$ and streaking on NA. A single-colony isolate that was $\mathrm{P}^{-}$and $\mathrm{Ap}^{\mathrm{s}}$ was considered cured. $\mathrm{CD} 70$ is a $\mathrm{P}^{+}$derivative of CD68. It was isolated from a cross between CD63(P::Tnl) and CD68 and selected on NA + Sm + Ap. KB365(P:: Tn $l)$ was isolated from a cross between CD63(P::Tnl) and KB365 (a spontaneous Sm mutant of strain 569B Inaba) and selected on NA + Sm + Ap.

$V$. cholerae $\mathrm{CD} 60$ is a choleragenoid-producing strain screened from among $\mathrm{P}^{+} \mathrm{V}^{+}$attenuated isolates of strain 569B Inaba. The $P$ and $V$ plasmids were transferred by conjugation from strains $K B 9(P)$ and $K B 9(V)$.

Isolation of strains $C D 65$ and CD66, carrying ts $P:: T n l$. The plasmid ts $\mathrm{P}:: \mathrm{Tn} l$, whose replication is inhibited at $42^{\circ} \mathrm{C}$ but unaffected at $30^{\circ} \mathrm{C}$, was isolated as follows. $V$. cholerae $\mathrm{CD} 63$ was grown exponentially to $5 \times 10^{8}$ cells $\mathrm{ml}^{-1}$ in BHI. The bacteria were washed and suspended in sodium citrate buffer (pH 5.5, $0 \cdot 1 \mathrm{M}$ ) containing $N$ methyl- $N^{\prime}$-nitro- $N$-nitrosoguanidine $\left(150 \mu \mathrm{g} \mathrm{ml}^{-1}\right)$ and shaken for $20 \mathrm{~min}$ at $37^{\circ} \mathrm{C}$. The mutagenized bacteria were washed with PBS and suspended in $10 \mathrm{ml}$ BHI containing ampicillin and shaken overnight at $30^{\circ} \mathrm{C}$, then crossed with $V$. cholerae $\mathrm{KB} 365$ at a ratio of $1: 9$ at $30^{\circ} \mathrm{C}$ for $90 \mathrm{~min}$. The mating mixture was streaked on $\mathrm{NA}+\mathrm{Sm}+\mathrm{Ap}$, incubated at $30^{\circ} \mathrm{C}$ for $12-14 \mathrm{~h}$ and examined for small isolated colonies. The plates were then moved to $42^{\circ} \mathrm{C}$ for $8 \mathrm{~h}$ to select probable ts mutants on the basis of small colony size. The tiny colonies with arrested growth at $42^{\circ} \mathrm{C}$ were tested on NA + Ap at $30^{\circ} \mathrm{C}$, on NA at $42^{\circ} \mathrm{C}$, and on NA + Ap at $42^{\circ} \mathrm{C}$. Colonies not growing at $42^{\circ} \mathrm{C}$ on one or both were considered to have the ts plasmid. (The presence of the P plasmid was tested as described below.) Two of these isolates, designated CD65 and CD66, were retained for curing studies.

Test for plasmid carriage. Presence of plasmid was determined by the growth-thinning effect of $\mathrm{P}^{+} / \mathrm{V}^{+}$strains on the plasmid-negative strain KB9 (Bhaskaran, 1964). Strain KB9 $\left(0.2 \mathrm{ml}\right.$, about $2 \times 10^{8}$ cells) was mixed in $7 \mathrm{ml}$ soft agar and poured on a NA plate. A loopful of the test culture was placed on the lawn of KB9 and incubated overnight at $30^{\circ} \mathrm{C}$ or $37^{\circ} \mathrm{C}$ as specified in the text. In addition, the presence of $\mathrm{P}:: \mathrm{Tn} l$ and its derivatives was determined by the Apr character of the bacteria.

Preparation and assay of toxin. Toxin was obtained by growing bacteria in syncase sucrose minimal medium at $28^{\circ} \mathrm{C}$ for $16 \mathrm{~h}$ in a shaker. Bacteria-free culture filtrate was obtained by membrane filtration (Millipore, $0.22 \mu \mathrm{m}$ pore size). Toxin antigen was quantified in vitro by radial immunodiffusion. Rabbit antitoxin antibodies were mixed in $2 \%(\mathrm{w} / \mathrm{v})$ agarose gel into which wells of equal diameter were cut. The wells were charged with $20 \mu \mathrm{l}$ of toxin preparations. With known concentrations of pure toxin, there was a linear relationship between toxin concentration and the square of the diameter of the antigen-antibody reaction zone. Toxin was measured in rivo in adult albino guinea-pigs (Craig, 1965). Culture filtrate was diluted in BHI and $0 \cdot 1 \mathrm{ml}$ was injected intradermally. Induration was recorded after $18 \mathrm{~h}$. BHI alone caused no induration. With known preparations of pure toxin, the diameter of the zone of induration showed a linear relationship to the log of the concentration of toxin, within the range $5-30 \mathrm{~mm}$.

Sensitization of sheep red blood cells $(S R B C)$ by cholera toxin and its $A$ and $B$ subunits. Fresh SRBC were sensitized by the method of Hochstein et al. (1970). Briefly, SRBC were washed three times in cold saline $(0.85 \%)$ and the cells were suspended to a final concentration of $5 \%(\mathrm{v} / \mathrm{v})$ in pure toxin $(15 \mu \mathrm{g}$ per ml saline) or A or B subunit toxin (each $25 \mu \mathrm{g}$ per $\mathrm{ml}$ saline; all purchased from Calbiochem, USA). The suspension was incubated for $30 \mathrm{~min}$ at $22{ }^{\circ} \mathrm{C}$ and washed three times in cold saline. Between 80 and $85 \%$ cells were sensitized. The extent of sensitization $(\%)$ was measured by a complement-mediated lysis test. Antitoxin serum, heated to $56{ }^{\circ} \mathrm{C}$ for 30 min to inactivate complement, was absorbed with SRBC to remove naturally occurring antibodies against SRBC. Then the serum $(0.3 \mathrm{ml})$ was incubated with $0.3 \mathrm{ml}$ toxin-sensitized $\mathrm{SRBC}$ at $22^{\circ} \mathrm{C}$ for $40 \mathrm{~min}$. Cells were washed once and $0.3 \mathrm{ml}$ $10 \%(\mathrm{v} / \mathrm{v})$ guinea-pig complement was added. As controls, equal amounts of sensitized SRBC were incubated separately with antibody, complement or water. After incubation at $37^{\circ} \mathrm{C}$ for $1 \mathrm{~h}$, the absorbance of the cleared supernatants were recorded at $520 \mathrm{~nm}$.

Titration of serum antibody. Antitoxin levels were determined by a passive haemagglutination (HA) test with toxin-sensitized SRBC (Hochstein et al., 1970). Briefly, $0.3 \mathrm{ml}$ of serial dilutions of sera were mixed with $0.3 \mathrm{ml}$ sensitized SRBC in HA plates and incubated for $2 \mathrm{~h}$ at $37^{\circ} \mathrm{C}$ followed by overnight incubation at $4{ }^{\circ} \mathrm{C}$. Titres were recorded as the highest serum dilution showing positive $\mathrm{HA}$. If no HA activity was detected in a dilution of 1 in 20 , the serum was considered to lack antitoxin antibodies.

Immunization of rabbits with culture filtrates. Albino rabbits weighing $1-1.2 \mathrm{~kg}$ were immunized by two subcutaneous injections, two weeks apart, of $1 \mathrm{ml}$ bacteria-free culture filtrate. Two weeks after the second dose, blood was withdrawn for serum antibody titration and rabbits were challenged by the ileal loop test to measure protection (Sinha \& Srivastava, 1978b).

\section{RESULTS}

Characterization of $P:: T n l$

The effect of plasmid $P:: T n 1$ on toxin biosynthesis was compared with that of plasmid $P$ by measuring toxin in the culture filtrates of $\mathrm{KB} 365, \mathrm{~KB} 365(\mathrm{P})$ and $\mathrm{KB} 365(\mathrm{P}:: \mathrm{Tn} 1)$. Toxin 
Table 1. Assay of toxin in the culture filtrate of parent $P^{-}, P^{+}$and cured strains of $V$. cholerae

\begin{tabular}{|c|c|c|c|}
\hline Strain & $\begin{array}{l}\text { Plasmid } \\
\text { status }\end{array}$ & Relevant markers* & $\begin{array}{c}\text { Toxin } \dagger \\
\left(\mu \mathrm{g} \mathrm{ml}^{-1}\right)\end{array}$ \\
\hline KB365 & - & $\mathrm{Sm}^{r}$, derivative of $569 \mathrm{~B}$ Inaba & $17 \cdot 0 \pm 1 \cdot 2$ \\
\hline K B365(P) & $\mathrm{P}$ & $\mathrm{Sm}^{r}$ & $1.5 \pm 0.45$ \\
\hline $\mathrm{KB} 365(\mathrm{P}:: \operatorname{Tn} l)$ & $\mathrm{P}:: \operatorname{Tn} l$ & $\mathrm{Sm}^{r} \mathrm{Ap} \mathrm{p}^{r}$ & $1.6 \pm 0.2$ \\
\hline CD65 & ts $P:: \operatorname{Tn} I$ & $\mathrm{Sm}^{\mathrm{T}} \mathrm{A} \mathbf{r}^{\mathrm{r}}$, derivative of $\mathrm{KB} 365$ & $1.4 \pm 0.4$ \\
\hline CD66 & ts $P:: \operatorname{Tn} I$ & $\mathrm{Sm}^{r} \mathrm{Ap}{ }^{r}$, derivative of $\mathrm{KB} 365$ & $1.6 \pm 0.4$ \\
\hline CD68 & 'Cured' & $\mathrm{Sm}^{\mathrm{r}}$, derivative of CD66 & $15.75 \pm 1.5$ \\
\hline CD70 & $\mathrm{P}:: \operatorname{Tn} I$ & $\mathrm{Sm}^{r} \mathrm{Ap}{ }^{r}$, derivative of $\mathrm{CD} 68$ & $1.3 \pm 0.4$ \\
\hline
\end{tabular}

${ }^{*} \mathrm{Sm}^{\mathrm{r}}$, streptomycin resistant $\left(500 \mu \mathrm{g} \mathrm{ml}^{-1}\right) ; \mathrm{Ap}$, ampicillin resistant $\left(100 \mu \mathrm{g} \mathrm{ml}^{-1}\right)$.

$\dagger$ Toxin was measured in vitro by radial immunodiffusion and in vivo in guinea-pigs with purified toxin as standard. The results are means of four replicate in vitro experiments, \pm SEM. The in vivo test gave closely similar results.

biosynthesis was inhibited by both plasmids, indicating that transposition of $\operatorname{Tn} l$ onto $\mathrm{P}$ did not affect the ability to suppress toxin biosynthesis (Table 1).

\section{Characterization of ts $P:: \operatorname{Tn} 1$}

As described in Methods, 2000 small colonies were tested on NA + Ap at $30^{\circ} \mathrm{C}$, on NA at $42^{\circ} \mathrm{C}$ and on NA $+\mathrm{Ap}$ at $42^{\circ} \mathrm{C}$. Nineteen colonies were temperature sensitive; they fell into two groups. Group I comprised 13 isolates which grew at $42^{\circ} \mathrm{C}$ on NA but not on NA + Ap. CD65 is representative of this group. Group II comprised six isolates, characterized by their inability to grow at $42{ }^{\circ} \mathrm{C}$ irrespective of medium, i.e. the plasmids had conferred the ts phenotype on the bacteria. CD66 is one of the isolates of this group. It should be remembered that ts plasmids were characterized after transfer to unmutagenized host KB365. This behaviour can be explained if it is assumed that the plasmid has integrated into the chromosome and the plasmid's origin of replication is being utilized. A similar observation, termed integrative suppression, was reported in E. coli by Nishimura et al. (1971). The 19 isolates were otherwise similar in growth and ampicillin resistance at $30^{\circ} \mathrm{C}$, presence of $\mathrm{P}$ plasmid (determined in the thinning of growth test) and suppressed synthesis of toxin.

Curing the bacteria of plasmids

In view of our objective of obtaining a ts $\mathrm{P}:: \mathrm{Tn} /$ which could be eliminated at $42{ }^{\circ} \mathrm{C}$ without affecting bacterial growth, ts mutants of both groups described above were examined.

Group I. The bacteria were grown at $42^{\circ} \mathrm{C}$ in BHI and suitable dilutions were plated on NA and $\mathrm{NA}+\mathrm{Ap}$ and incubated at $30^{\circ} \mathrm{C}$. No difference was observed in the number of colonies on the two media, and all the colonies were $\mathrm{P}^{+}$in the thinning of growth test. This suggested that cells were not cured of plasmids.

Group II. The six isolates of this group could grow at $30^{\circ} \mathrm{C}$ but not at $42^{\circ} \mathrm{C}$ on any medium. However, after a few subcultures at $30^{\circ} \mathrm{C}$, one of the isolates $(\mathrm{CD} 66)$ was able to grow at $42^{\circ} \mathrm{C}$ in BHI. After growth of strain CD66 at $42^{\circ} \mathrm{C}$ for $4 \mathrm{~h}$, suitable dilutions were plated on NA and $\mathrm{NA}+\mathrm{Ap}$ and incubated at $30^{\circ} \mathrm{C}$. Colonies appeared on NA but not on NA + Ap, suggesting $100 \%$ loss of ampicillin resistance. These $\mathrm{Ap}^{\mathrm{s}}$ colonies were $\mathrm{P}^{-}$in the thinning of growth test. Thus $100 \%$ curing of CD66 was observed when it was grown at $42{ }^{\circ} \mathrm{C}$ in $\mathrm{BHI}$. The cured derivative of CD66 was designated CD68.

\section{Assay of cholera toxin in $P^{+}$and cured strains}

Toxin was measured in the culture filtrates of the parent $\mathrm{P}^{-}, \mathrm{P}^{+}$and cured strains (Table 1). All the strains are isogenic. While $\mathrm{P}^{+}$strains made less toxin than the $\mathrm{P}^{-}$parent $\mathrm{KB} 365$, the quantity of toxin in the filtrates of the cured strain CD68 was similar to that observed for K B365. Re-introduction of the $\mathrm{P}$ plasmid into the cured strain resulted in the suppression of toxin biosynthesis (CD70, Table 1). 


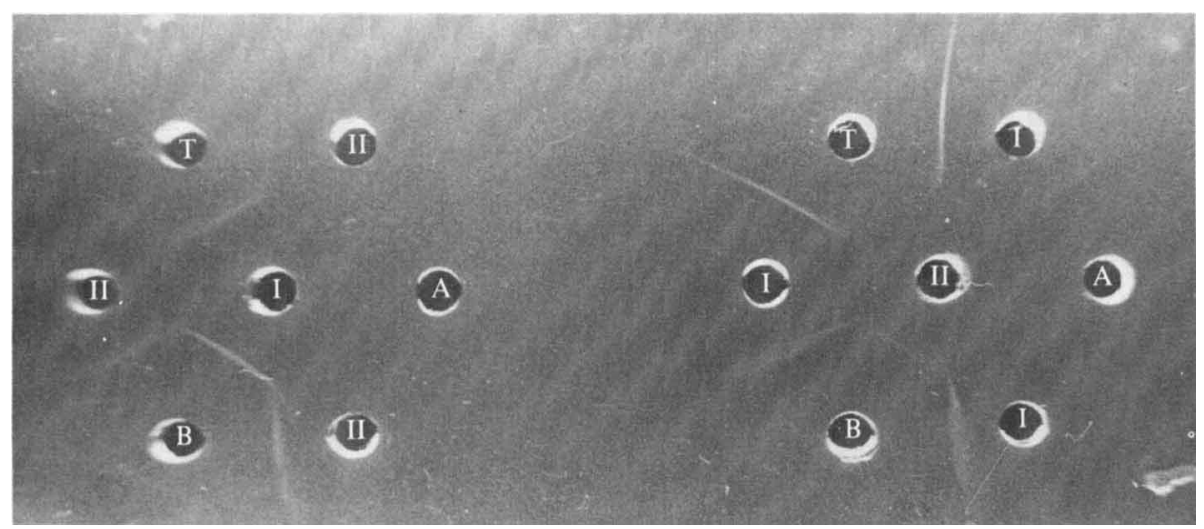

Fig. 1. Ouchterlony test of preparation from strains 569B and CD60: rabbit-anti-569B-toxin (I), rabbitanti-CD60-mutant toxin (II), toxin (T), A subunit (A), B subunit (B). (The lines of precipitation between $\mathrm{I}$ and $\mathrm{A}$ are very faint.)

Table 2. Serum antitoxin titre and protection in rabbits immunized with bacteria-free culture filtrate $(C F)$ of $C D 60$ and $569 B$

Six animals of the same age were used in each group. Four ileal loops were made in each rabbit; two were challenged with toxin and two with $V$. cholerae 569B Inaba. Hence for each group antitoxin titre is the mean $( \pm$ SEM) of titres obtained independently from six rabbits, whereas the percentage protection data represent means $( \pm$ SEM) of 10-12 loops. Antitoxin titres were measured in sera from rabbits immunized with 3-4 batches of culture filtrate prepared on different days. The protection experiment was done twice, each time with six rabbits in each group.

$\begin{array}{cccc}\text { Vaccine } & \begin{array}{c}\text { Antitoxin } \\ \text { titre }\end{array} & \begin{array}{c}\text { Challenged } \\ \text { with* }\end{array} & \begin{array}{c}\text { Protection against } \\ \text { challenge }(\%)\end{array} \\ \text { Control } \ddagger & <20 & \begin{array}{c}569 \mathrm{~B} \\ \text { Toxin }\end{array} & 0 \\ \text { CF of CD60 } & 200 \pm 8 & \begin{array}{c}569 \mathrm{~B} \\ \text { Toxin }\end{array} & 47 \pm 12 \\ \text { CF of 569B } & 800 \pm 0 & 569 \mathrm{~B} & 60 \pm 13 \\ & & \text { Toxin } & 63 \pm 10\end{array}$

* $10^{5}$ colony-forming units of $569 \mathrm{~B}$ or $10 \mu \mathrm{g}$ of pure cholera toxin in ligated ileal loops; both elicited 1.5-1.8 ml fluid $(\mathrm{cm} \text { loop })^{-1}$ in control rabbits.

+ Percentage protection is calculated as $(x / y) \times 100$, where $x$ is the volume of fluid $\left(\mathrm{ml} \mathrm{cm}^{-1}\right)$ in the ileal loops of immunized rabbits, and $y$ is the volume of fluid in the ileal loops of control, non-immunized rabbits.

$\ddagger$ Sterile culture medium.

\section{Characterization of strain CD60, producing choleragenoid}

CD60 is an attenuated $\mathrm{P}^{+} \mathrm{V}^{+}$mutant of $V$. cholerae 569B Inaba: neither CD60 nor its culture filtrate had any detectable cholera toxin-like activity. As reported earlier (Sinha \& Srivastava, $1978 a$ ), strain 569B caused accumulation of fluid in the ileal loops of rabbit. When rabbits were immunized with bacteria-free culture filtrate of $\mathrm{CD} 60$, antitoxin antibodies were detected in the serum and rabbits were protected from challenge with pathogenic strains or cholera toxin (Table 2). Similar results were obtained with culture filtrate of 569B. These results strongly suggest that CD60 released choleragenoid, which was nontoxic but immunogenic.

A simple Ouchterlony test in $2 \%(\mathrm{w} / \mathrm{v})$ agarose suggested that the mutant toxin synthesized by CD60 can be characterized as $\mathrm{A}^{-} \mathrm{B}^{+}$(Fig. 1). Additionally, when SRBC sensitized by the A or the $B$ subunit of cholera toxin were mixed with anti-CD60-toxin antibodies, positive HA was observed only with B-sensitized SRBC.

\section{DISCUSSION}

Sinha \& Srivastava (1978 a) reported attentuation of virulence caused by $\mathbf{P}$ and $\mathbf{V}$ plasmids in $V$. cholerae, due to production of less toxin. Neither the mechanism inhibiting toxin biosynthesis 
nor the effect of loss of plasmid on toxin biosynthesis was known. Considerable insight would be gained if the plasmids could be eliminated from the cells and toxin production examined. With this objective, ts mutants of the $P$ plasmid were isolated whose replication was inhibited at $42^{\circ} \mathrm{C}$.

Strains cured of the P plasmid resumed toxin biosynthesis like the parent strain and were relieved of the suppression caused by the plasmid. Reacquisition of the P plasmid by the cured strain again resulted in suppression. These results support the hypothesis that toxin biosynthesis is regulated by plasmid-borne genes. Moreover, plasmids seem to play a unique regulatory role in toxin biosynthesis of $V$. cholerae. Not only is synthesis of toxin inhibited, but modulation of the cells to produce choleragenoid can be achieved. CD60 is a unique type of vaccine strain that is both attentuated by plasmids and synthesizes a mutant toxin $\left(\mathrm{A}^{-} \mathrm{B}^{+}\right)$.

Cloning of cholera toxin genes and the genetic mapping of regulatory mutants of $V$. cholerae have demonstrated that these loci are located on the chromosome (Gennaro et al., 1982; Mekalanos et al., 1979, 1983; Kaper et al., 1984). The results reported in this paper strongly suggest that genes regulating toxin biosynthesis in $V$. cholerae are also located on the P plasmid.

We are grateful to Dr Nitya Nand, Director of the Institute, for facilities and to Dr M. Faelen, Universite Libre de Bruxelles, for useful discussion and suggestions. Thanks are due to Mr M. U. Khan and Mr A. K. Sarkar for laboratory assistance. A.A.K. was supported by a Junior Research Fellowship of the Council of Scientific and Industrial Research, New Delhi. This is communiation no. 3595 of this Institute.

\section{REFERENCES}

BHASKaRAN, K. (1964). Segregation of genetic factors during recombination in Vibrio cholerae strain 162. Bulletin of the World Health Organization 30, 845853.

Craig, J. O. (1965). The effect of cholera stool and culture filtrates on the skin of guinea-pigs and rabbits. In Proceedings of the Cholera Research Symposium 1965, Honolulu, Hawaii, pp. 153-158. Washington: US Government Printing Office.

Finkelstein, R. A. (1962). Vibriocidal antibody inhibition (VAI) analysis: a technique for the identification of the predominant vibriocidal antibodies in serum and for Vibrio cholerae antigens. Journal of Immunology 89, 264-271.

Finkelstein, R. A. \& LoSpalluto, J. J. (1969). Pathogenesis of experimental cholera: preparation and isolation of choleragen and choleragenoid. Journal of Experimental Medicine 130, 185-202.

Gennaro, M. L., Greenaway, P. J. \& Broadbent, D. A. (1982). The expression of biologically active cholera toxin in Escherichia coli. Nucleic Acids Research 10, 4883-4890.

GiLl, D. M. (1976). The arrangement of subunits in cholera toxin. Biochemistry 15, 1242-1248.

Gill, D. M. \& MEREN, R. (1978). ADP-ribosylation of membrane proteins catalysed by cholera toxin: basis of activation of adenylate cyclase. Proceedings of the National Academy of Sciences of the United States of America 75, 3050-3054.

Hochstein, H. D., Feeley, J. C. \& Richardson, S. H. (1970). Titration of cholera antitoxin levels by passive haemagglutination tests using fresh and formalinized sheep erythrocytes. Proceedings of the Society of Experimental Biology and Medicine 133, $120-124$

Holmgren, J., Svennerholm, A. M., Lonnroth, I.. Fallpersson, M., Markman, B. \& Lundback, $\mathrm{H}$. (1977). Development of improved cholera vaccine based on subunit toxoid. Nature, London 269, 602 604.

Honda, T. \& Finkelstein, R. A. (1979). Selection and characteristics of novel Vibrio cholerae mutant lacking the A (ADP-ribosylating) portion of the cholera enterotoxin. Proceedings of the National Academy of Sciences of the United States of America 76, 2052-2056.

Kaper, J. B., Lockman, H., Baldini, M. M. \& Levine, M. M. (1984). Recombinant nontoxinogenic Vibrio cholerae strains as attenuated cholera vaccine candidates. Nature, London 308, 655-658.

Mekalanos, J. J., Sublett, R. D. \& Romig, W. R. (1979). Genetic mapping of toxin regulatory mechanisms in Vibrio cholerae. Journal of Bacteriology 139, 859-865.

Mekalanos, J. J., Swartz, D. J., Pearson, G. D. N., Harford, N., Groyne, F. \& Wilde, M. D. (1983). Cholera toxin genes: nucleotide sequence, deletion analysis and vaccine development. Nature, London 306, 551-557.

Nishimura, Y., Caro, L., Berg, C. M. \& Hirota, Y. (1971). Chromosome replication in Escherichia coli. IV. Control of chromosome replication and cell division by an integrated episome. Journal of Molecular Biology 55, 441-456.

Sinha, V. B. \& SRIvastava, B. S. (1978a). Suppression of pathogenicity by $\mathrm{P}$ and $\mathrm{V}$ plasmids in Vibrio cholerae. Journal of General Microbiology 104, 251255

Sinha, V. B. \& SRivastava, B. S. (1978b). Plasmidinduced loss of virulence in Vibrio cholerae. Nature, London 276, 708-709.

Sporecke, I., Castro, D. \& Mekalanos, J. J. (1984). Genetic mapping of Vibrio cholerae enterotoxin structural genes. Journal of Bacteriology 157, 253261. 